\section{(6) OPEN ACCESS}

\title{
Intracranial arachnoid cyst rupture after mild TBI in children: have we underestimated this risk?
}

\author{
Leopoldo Mandic Ferreira Furtado, ${ }^{1,2}$ José Aloysio Costa Val Filho, ${ }^{3}$ \\ Raquel Ida Ferreira, ${ }^{4}$ Italo Guilherme Giarola de Freitas Mariano ${ }^{4}$
}

${ }^{1}$ Pediatric Neurosurgery, Biocor Instituto, Nova Lima, Brazil

${ }^{2}$ Neurotraumatology, Fundacao Hospitalar do Estado de Minas Gerais, Belo Horizonte, Brazil ${ }^{3}$ Pediatric Neurosurgery, Vila da Serra Hospital, Nova Lima, Brazil ${ }^{4}$ Faculdade de Medicina de Barbacena, Barbacena, Brazil

\section{Correspondence to}

Leopoldo Mandic

Ferreira Furtado,

Imandicster@gmail.com

Accepted 13 April 2019

\section{SUMMARY}

The association between intracranial arachnoid cyst rupture and mild brain trauma is infrequently reported. The purpose of this case report is to describe the case of a child with a left temporal arachnoid cyst who suffered rupture with haemorrhage after mild trauma during a football match. The child presented with chronic headache of mild intensity that progressed to a more intense headache after a traumatic event. He underwent surgical intervention after diagnosis of chronic haemorrhage in an arachnoid cyst in the ipsilateral subdural space. The risk of intracranial arachnoid cyst rupture should be considered during the evaluation of oligosymptomatic patients because it is a potentially catastrophic event.

\section{BACKGROUND}

Intracranial arachnoid cysts are uncommon among children and may account for up to $2.6 \%$ of expanding intracranial lesions. ${ }^{12}$ Their most frequent location is the middle fossa. Most are asymptomatic or present with headache, convulsions and haemorrhage..$^{2-4}$

Haemorrhages are uncommon and potentially catastrophic events, and their pathophysiology is unclear; they may arise after traumatic brain injury (TBI) or spontaneously. ${ }^{56}$

Traumas, even those with low kinetic energy, are a risk factor for intracystic haemorrhage due to the pressure imbalance and the rupture of the blood vessels within the lesion. In addition, the incidence of intracystic haemorrhage is related to lesion size, especially when the lesion is larger than $5 \mathrm{~cm}^{2}$

The treatment of choice for arachnoid cysts with haemorrhage is surgical, consisting of haematoma drainage and cyst fenestration into the subarachnoid space, with the objective of restoring cerebrospinal fluid flow. ${ }^{3}$

Currently, the indication of surgical treatment for asymptomatic arachnoid cysts is controversial. ${ }^{6}$ The argument in favour of conservative treatment is based

(c) BMJ Publishing Group Limited 2019. Re-use permitted under CC BY-NC. No commercial re-use. See rights and permissions. Published by BMJ.

\begin{tabular}{l}
\hline To cite: Furtado LMF, \\
Costa Val Filho JA, \\
Ferreira Rl, et al. BMJ Case \\
Rep 2019;12:e228790. \\
doi:10.1136/bcr-2018- \\
228790
\end{tabular}

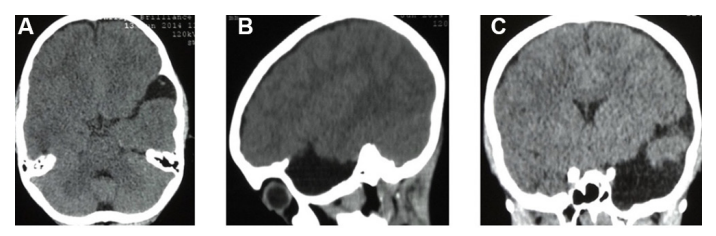

Figure 1 CT of the head without contrast showing a Galassi type II left temporal arachnoid cyst. Axial (A), sagittal (B) and coronal (C) views.

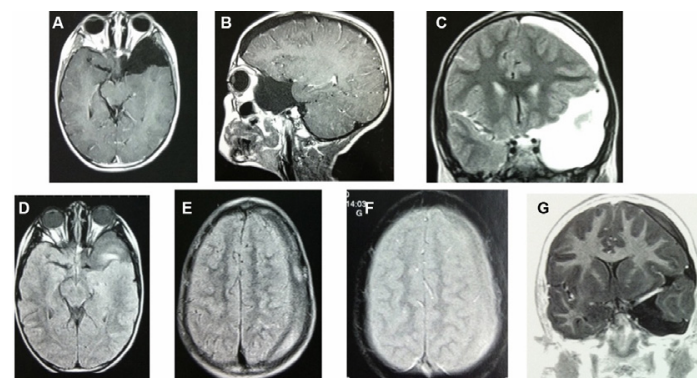

Figure 2 Preoperative MRI of the brain during endoscopic surgery planning 1 month after a CT scan of the head showed chronic subdural haematoma. Axial (A) and sagittal (B) T1-weighted images with contrast. Coronal (C), flair axial $(D, E)$, STIR (F) and gradient-echo (G) T2-weighted images.

on the low incidence of cyst rupture, which occurs in approximately $6 \%$ of patients. ${ }^{2}$

This report describes a case of haemorrhage in a temporal arachnoid cyst after mild TBI.

\section{CASE PRESENTATION}

An 8-year-old boy complained of a weekly recurring left frontotemporal headache, occurring in the morning since the age of 8 , with an intensity of five on the visual analogue scale (VAS) for pain and a
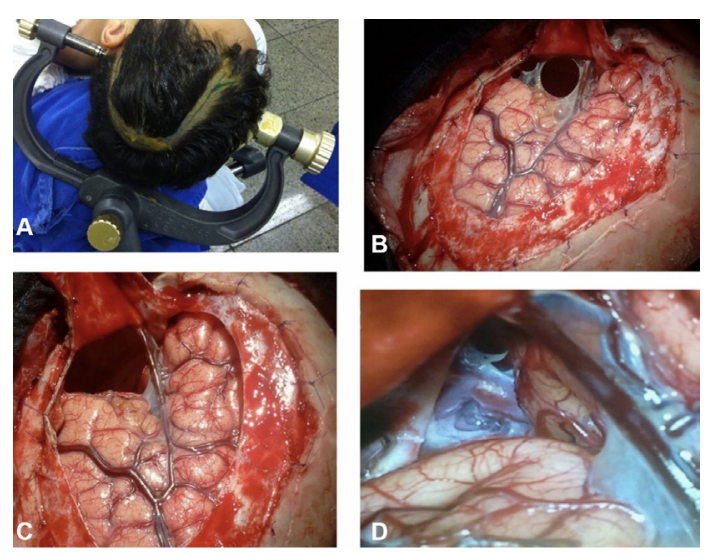

Figure 3 Microsurgery for drainage of the subdural haematoma and fenestration of the arachnoid cyst. Demarcation of the incision by hair shaving (A), followed by frontotemporoparietal craniotomy, drainage of the chronic subdural haematoma, partial fenestration of the external cyst wall (B) and complete fenestration (C). Microsurgical fenestration of the Liliequist membrane (D). 

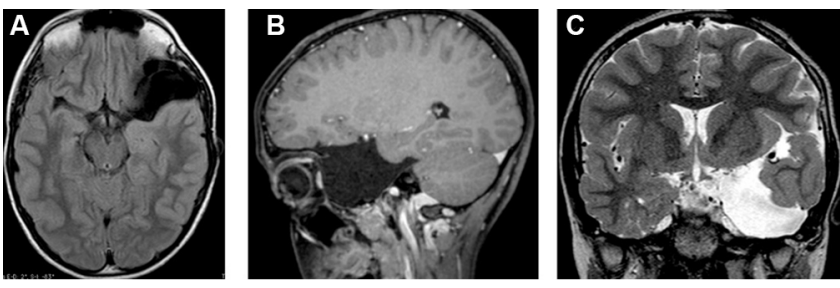

Figure 4 Follow-up MRI of the brain 3 years after the surgery. Axial (A) and sagittal (B) T1-weighted images. Axial T2-weighted image (C).

sensation of tightening. The pain was responsive to common analgesics, and no triggering factors were detected. The patient had normal cognitive development for his age. A left temporal Galassi type II arachnoid cyst (figure 1) was diagnosed, and elective endoscopic surgery was planned; MRI of the brain was performed for surgical planning.

The patient suffered a mild TBI during a football match due to a head collision, without loss of consciousness or other signs of severity during the acute trauma phase. The headache intensified $(\mathrm{VAS}=8$ ) 30 days after the event, becoming continuous and refractory to analgesia and associated with vomiting and double vision.

On neurological examination, the patient had Glasgow score of 15 , with no pupillary, language or motor changes but with left lateral rectus muscle paresis. MRI of the brain revealed a haemorrhage in the Galassi type III left temporal arachnoid cyst and an ipsilateral subdural haematoma (figure 2).

The child was hospitalised as an emergency case for microsurgery. Left pterional craniotomy, haematoma drainage and microsurgical fenestration of the arachnoid cyst, creating a communication with the interpeduncular cistern, were performed (figure 3).

\section{OUTCOME AND FOLLOW-UP}

An improvement of the headache occurred during the immediate postoperative period and an improvement in double vision occurred after 15 days.

During a 3-year follow-up period, no adverse events were recorded, and the arachnoid cyst volume was reduced (figure 4).

\section{DISCUSSION}

The reported case demonstrated that mild TBI is a determinant for arachnoid cyst rupture. A case control study found that trauma occurring within 30 days may increase the risk of rupture of arachnoid cysts by up to 26.5 -fold. A cyst size greater than $50 \mathrm{~mm}$ was also considered a risk factor for this event. ${ }^{27}$

Concerning the estimation of this risk in children, it should be considered that natural recreational activity constitutes a permanent risk for the rupture of these cysts. This factor should be considered during surgical decision making for oligosymptomatic and asymptomatic cases. ${ }^{25}$

After cyst rupture and haemorrhage, endoscopic surgery becomes technically difficult due to poor visibility and orientation within the cyst and poor visibility through the membranes, preventing safe fenestration. ${ }^{6}$

Therefore, microsurgery with cyst fenestration to the interpeduncular and optic chiasmatic cisterns should be chosen.

\section{Learning points}

- Arachnoid cyst may bleed.

- Bleeding should be a severe complication.

- Children are more susceptible to bleed due to major incidence of mild head trauma.

- The haemorrhage treatment is aways by open surgery.

Contributors LMFF: responsible for conception, design and conducted the operation on the child. JACVF: responsible for discuss planing, analysis and interpretation of data. RIF: made acquisition of data and writing. IGGdFM: made acquisition of data and writing.

Funding The authors have not declared a specific grant for this research from any funding agency in the public, commercial or not-for-profit sectors.

Competing interests None declared.

Patient consent for publication Parental/guardian consent obtained.

Provenance and peer review Not commissioned; externally peer reviewed.

Open access This is an open access article distributed in accordance with the Creative Commons Attribution Non Commercial (CC BY-NC 4.0) license, which permits others to distribute, remix, adapt, build upon this work non-commercially, and license their derivative works on different terms, provided the original work is properly cited and the use is non-commercial. See: http://creativecommons.org/ licenses/by-nc/4.0/

\section{REFERENCES}

1 Aydogmus E, Hicdonmez T. Spontaneous Intracystic Haemorrhage of an Arachnoid Cyst Associated with a Subacute Subdural Hematoma: A Case Report and Literature Review. Turk Neurosurg 2017;17:1-5.

2 Cress M, Kestle JR, Holubkov R, et al. Risk factors for pediatric arachnoid cyst rupture/ hemorrhage: a case-control study. Neurosurgery 2013;72:716-22.

3 Eustace S, Toland J, Stack J. CT and MRI of arachnoid cyst with complicating intracystic and subdural haemorrhage. J Comput Assist Tomogr 1992;16:995-7.

4 Galassi E, Piazza G, Gaist G, et al. Arachnoid cysts of the middle cranial fossa: a clinical and radiological study of 25 cases treated surgically. Surg Neurol 1980;14:211-9.

5 laconetta G, Esposito M, Maiuri F, et al. Arachnoid cyst with intracystic haemorrhage and subdural haematoma: case report and literature review. Neuro/ Sci 2006:26:451-5.

6 Lee JY, Kim JW, Phi JH, et al. Enlarging arachnoid cyst: a false alarm for infants. Childs Nerv Syst 2012;28:1203-11.

7 Pascoe HM, Phal PM, King JA. Progressive post traumatic tearing of an arachnoid cyst membrane resulting in intracystic and subdural haemorrhage. J Clin Neurosci 2015;22:897-9. 
Copyright 2019 BMJ Publishing Group. All rights reserved. For permission to reuse any of this content visit https://www.bmj.com/company/products-services/rights-and-licensing/permissions/

BMJ Case Report Fellows may re-use this article for personal use and teaching without any further permission.

Become a Fellow of BMJ Case Reports today and you can:

- Submit as many cases as you like

- Enjoy fast sympathetic peer review and rapid publication of accepted articles

- Access all the published articles

- Re-use any of the published material for personal use and teaching without further permission

For information on Institutional Fellowships contact consortiasales@bmjgroup.com

Visit casereports.bmj.com for more articles like this and to become a Fellow 